\title{
Representing National Culture, Values and Identity in the Brazilian Television Mini- series
}

\author{
NIALL BRENNAN, London School of Economics
}

\section{ABSTRACT}

The telenovela is a significant indicator of social and cultural representation on Brazilian nightly television. In this context, however, representations of Brazil are not entirely limited to the telenovela, but incorporate other devices that represent a broader spectrum of Brazil's diverse societies and cultures. In this article, I discuss how the Brazilian television mini-series provides such a unique and unacknowledged ambit, reflecting discernible continuities and changes in Brazilian national cultures, values and identities. The concept of hybridity forms a theoretical framework for the following discussions. Methodologically, I relate data from textual, press and interview analyses to the research question and discuss how this reveals additional discourses of representation. As a result, the mini-series, rather than implicitly mirroring the production and viewing characteristics of the telenovela, explicitly engages with pedagogical devices such as imagination, perception and (un)familiarity, greatly expanding Brazilian television's social-cultural representations of Brazil.

\section{KEYWORDS}

Brazil; hybridity; mini-series; pedagogy; representation; television.

\section{Introduction}

In 2002, I moved to Brazil to teach English. What I expected to be a few months in fact turned into a stay of over a year. In Brazil, I realised the breadth and significance of television: how television is both integrated with daily life and how it forms part of Brazilian national identity. I witnessed how television informs and entertains, but also how it has become part of Brazilian social and cultural history, particularly Brazil's television dramas. As far as prime time, serialised drama is concerned, the telenovela is the best-known (and most widely-researched) type of Brazilian television programming, as well as the most obvious representation of 'what is Brazil' on Brazilian television. This is due not only to the fact that the telenovela attempts to integrate many of Brazil's present social and cultural conditions with its storylines, but also to the fact that it is an 'open work' where the storylines themselves are an incorporation of ongoing viewer feedback and response mechanisms.

The Brazilian television mini-series, however, offers an alternative picture of Brazil by creating a different set of representations that lead to a broader understanding of Brazilian culture and society. Also a form of prime time, serialised television drama, and still relying on the melodramatic traditions of the telenovela, the mini-series 
stands apart by drawing on various artistic, historical and biographical sources that are nevertheless consistently Brazilian, thus reflecting the nation's diverse social, cultural and geo-political histories. Additionally, and like the books, films or plays it often draws on, the mini-series is a 'closed work', not open to viewer feedback, and so a more focused attempt to reflect the cultures, values and identities of the people and eras it depicts, as well as those of its original authors and more recent creators. Taking all these considerations into account has led me to formulate the following research question, which guides this article and frames its theoretical, empirical and analytical discussions: In what ways does the Brazilian television mini-series represent continuities and changes in Brazilian national culture, values and identity?

\section{Hybridity and Postcolonial Culture}

My theoretical approach is based on the concept of hybridity. I approach hybridity from two levels: social-cultural and textual-generic hybridity. In other words, the mini-series represents Brazil's amalgam of different cultural and social contexts and conditions as much as it reflects how the forms and practices of these various cultures and societies come together in the mini-series texts and genre. Reviewing the literature on theoretical approaches to hybridity, representation and the means by which representation occurs are recurring, predominant concerns. In turn, these issues of 'representation' and 'represented' translate into theoretical concerns with, respectively, the establishment of cultural identity and the formation of cultural identification.

A primary context for theorising cultural identity and cultural identification is the postcolonial world. The work of three important theorists, in particular, centres on the hybridity of cultural identity and cultural identification within this context and its conditions. For Stuart Hall (1990, 1996, 2001), a hybrid cultural identity begins with 'a system where every concept or meaning is inscribed in a chain or a system within which it refers to the others, to other concepts and meanings by means of the systematic play of differences' (2001, p.11). In the postcolonial context, then, articulating forms and expressions as 'original' or 'authentic' culture result in a

cultural life ... nowhere to be found in its pure, pristine state. It is alwaysalready fused, syncretised, with other cultural elements. It is always-already creolised ... ever-present ... traversing and intersecting our lives at every point'

(Hall, 1990, p.233)

Thus, the formation of cultural identity and its predication upon cultural identification (Hall 2001, p.9) mean negotiating social-cultural differences by contending with their often competing forms and expressions.

In the work of Homi K. Bhabha $(1994,1996)$, hybridity is described as located in a 'Third Space' (1994, p.53). This is a metaphysical space of cultural negotiation in postcolonial societies; the location in which cultural forms and practices are contested by 'both colonialists and nationalists who have sought authority in the authenticity of "origins"... [but also] as a separation from [those] origins and essences [in which] this colonial space is constructed' (1994, p.171). Thus, in postcolonial culture, while 
this Third Space [might] have a colonial or postcolonial provenance.... [it also] open[s] the way to conceptualizing an international culture, based not on the exoticism of multiculturalism or the diversity of cultures, but on the inscription and articulation of culture's hybridity

(Bhabha, 1994, p.56; original emphases)

These ideas of the 'inscription and articulation' of hybrid cultural forms correlate as well with 'the discourses of pedagogy and the performative' (Bhabha, 1994, p.214), or 'the tension between ... people as an a priori historical presence ... [and] people constructed in the performance of narrative' (Bhabha, 1994, p.211), in the postcolonial space.

Hall and Bhabha's conceptualisations of the hybrid spaces of postcolonial culture through contested social-cultural identities are paralleled by the work of Paul Gilroy (1993, 2000). Gilroy conceives of the hybridity of postcolonial cultural identity as a state of 'double-consciousness' (1993, p.30; see also Du Bois, 1996, p.5), where the irreconcilable legacy of African slavery and the black diaspora to the Western world have framed the ambivalent state of modern black cultural identity. In Gilroy's work (1993) to trace this as a process beginning with African origins and ending more recently in modern black literature, he finds black cultural identity impeded by temporal and spatial constraints on both its cohesiveness and a consciousness of that cohesiveness. However, some modern black writers have inverted these very same temporal-spatial impediments, yielding a

transformation of cultural space and the subordination of distance ... that contribute to a parallel change in the significance of appeals to tradition, time, and history. In particular, the invocation of tradition becomes both more desperate and more politically charged as the sheer irrepressible heterology of black cultures becomes hard to avoid

(Gilroy, 1993, p.194)

Like the 'systematic play of differences' or the 'Third Space', then, 'double consciousness' underscores the historic, geographic and political struggles to form cultural identification and thus establish cultural identity in the postcolonial context. But at the same time, these conceptualisations of hybridity also underscore commensurate, parallel efforts to channel struggles with postcolonial cultural identity into an ambit of fruitful expression.

\section{Hybridity in Latin America}

As a concept, hybridity applies to the Latin American context as well. One important application lies in the term mestizaje. For Gloria Anzaldúa (2007 [1987]), mestizaje is situated in the ethnic and historical conditions of the southwest United States, where 'Indians and mestizos from central Mexico intermarried with North American Indians.... [and] continual intermarriage between Mexican and American Indians and Spaniards formed an even greater mestizaje' (2007 [1987], p.27). Hybridity, in other words, is a 'convergence [that] has created a shock culture, a border culture, a third country, a closed country' (Anzaldúa 2007 [1987], p.33). In the contentiousness of 
this context and its challenge both to Western and Indio-Mexican-Spanish cultural norms, Anzaldúa reflects:

Not only was the brain split into two functions but so was reality... [where] people who inhabit both realities are forced to live in the interface between the two, forced to become adept at switching modes

(2007 [1987], p.59)

Although, not discounting these ethno-historic implications, Jesús Martín-Barbero (1993, 2001) focuses on the importance of mestizaje for understanding the hybridity of Latin America's mass cultures. With mass culture, Martín-Barbero advocates

a new way of looking that, on one hand, reveals the actual span of hybridization between visuality and technicality and, on the other, redeems the imagistic as a location of a strategic cultural battle

(2001, p.15 - 16; original emphases)

These hybrid cultural battles of 'the imagistic' reveal not only the negotiation of cultural identity in Latin American 'made' society (that is, 'lived' and 'experienced' society), but also 'remade' culture (that is, mass representations of culture). Mestizaje, in other words, is a concept that applies to the hybrid sites, forms and practices of Latin American societies and mass cultures. Therefore, the negotiation of ethno-historic identity explicit in Anzaldúa's mestizaje is paralleled by implicit representations of those same negotiations of identity (that is, cultural identification) in Latin American mass culture. For example, shifts in cultural identity through ruralto-urban migration in Latin America and the resulting hybridity of Latin American urban mass culture illustrate this idea of mestizaje as a concept both 'made and remade' in Latin America:

Mass culture is the hybrid of foreign and national, of popular informality and bourgeois concern with upward mobility. It is the hybrid of two classic types: those who try to look rich without the means to do so ... and the opposite, those crushed by the hopelessness of the slums on the edges of the cities and in the underworld. Mass culture is essentially an urban culture which compensates its open materialism - the supreme values are economic success and social ascent - with a superabundance of the sentimental and the passionate

(Martín-Barbero, 1993, p.159)

For Néstor García Canclini (1995a, 1995b), capital is also central to these made/remade dimensions of cultural hybridity. Capital, in the social (see Bourdieu, 1977, p.184) and cultural (Bourdieu \& Passeron, 1990, pp. vii - xi) senses, intensifies the negotiation of cultural identity in Latin America. Through social and cultural capital and their varied contextual capacities, the traditional high-low (or urban-rural) schisms of Latin American modern identity, for example, are thrown aside, to be replaced by a new set of issues concerned with the material-economic aspects of Latin American postmodern identity. García Canclini's approach to hybridity highlights these postmodern dimensions of cultural identity (again, the 'made'), but also draws attention to how this impacts their representation through the reworking of Latin American cultural production (again, the 'remade'). Thus mestizaje has implications 
for interpreting modern Latin American cultural identity by emphasising divisions between social values ('economic success and social ascent') and cultural values ('the sentimental and the passionate'). Capital, however, has implications for interpreting postmodern Latin American cultural identity as it

has the advantage of not representing ... [any] set of stable and neutral goods with values and meanings that are fixed once and for all, but rather ... a social process that, like the other kind of capital, is accumulated, reconverted, produces yields, and is appropriated in an unequal way by different sectors

(García Canclini, 1995a, p.136; original emphasis)

The hybridity of Latin American cultural identity and mass culture thus requires 'different conceptual instruments' (García Canclini, 1995a, p.206) for its analysis and understanding. What is required is 'a substitute for what can no longer be understood under the signs of cultured or popular: the formula "urban culture" (García Canclini, 1995a, p.207). But where Martín-Barbero's notion of urban culture has been part of an 'attempt to contain the diverse forces of modernity' (García Canclini, 1995a, p.207), the material-economic forces of capital on postmodern Latin American culture reveal

three key processes for explaining hybridization: the breakup and mixing of the collections that used to organize cultural systems, the deterritorialization of symbolic processes, and the expansion of [their] impure genres ... [which] determine precisely the articulations between modernity and postmodernity, between culture and power

(García Canclini, 1995a, p.207)

\section{Hybridity and Brazil}

Brazil's mestizaje, conveyed by the term mestiçagem, has been contentious since Portuguese colonisation in the sixteenth century. But from the positivism of the nineteenth century to the totalitarianism of the twentieth, as traced by Renato Ortiz (1985; see also 1988, 1989), Brazil's social-cultural hybridity was an intellectual concern in which this contentiousness became inverted. Instead of conceiving of hybridity as a correlation between the environment and its inhabitant, as did nineteenth-century Brazilian intellectuals, the objective of the Vargas and military regimes was to consolidate Brazil's social-cultural hybridity, independent of environment or inhabitants. Therefore, ethnic difference and miscegenation yielded to social-cultural cohesiveness; in turn, this cohesiveness yielded to the military's objective of national security:

mestiçagem ... contained the precise traces that naturally defined Brazilian identity: unity in diversity. This ideological formula was condensed in two dimensions: the variety of cultures and the unity of the national. Within this perspective the [military] defined Brazilian culture as a product of the acculturation of diverse origins. [According to the military] [c]ulture 'derives from the syncretism of different manifestations that today we can identify as characteristically Brazilian, translating them in a sense that, although national, have regional particularities' 
(Ortiz, 1985, p.93)

The work of Émile Durkheim and Gilberto Freyre (1946, 1986) was key to the military's aspirations for a unified culture and society. In particular, Freyre's thesis on Brazil's racial equality and social harmony was leveraged by the military to 'resolve ... the very concept of differentiation, presupposing the existence of a harmonious and equilibrated society' (Ortiz, 1985, p.94). The military acted as protector and unifier of Brazil: a patrimonial role, like that of Getúlio Vargas thirty years earlier, of both caring for and uniting Brazil's diverse regions and cultures. This role was propelled by an underlying strategy of 'Tradition through Diversity', where 'Tradition signified the diversity and multiplicity of Brazilian culture .... [and] the objectivity of that culture ... translated into the material archive bequeathed by history' (Ortiz, 1985, p.96). Thus, protection meant preserving Brazilian national heritage, the physical and symbolic essence of Brazilian culture, and unification meant celebrating diversity, with both intended to cohere Brazilian national identity.

While this objective appears contradictory, it nevertheless reflects the military's logic in attempting to rationalise the complexity of hybrid cultural identities through a unified national identity. Attempts to accomplish this were first made where, through environment and nation, the military believed that separate yet equal regional loyalties would result in the nation's overall well-being, or where 'the national personality is the more elaborate expression of Brazilian culture, and by this, "to its defence [the former] will command itself as much as [it will command] the national territory", (Ortiz, 1985, p.101). Second, through ethnic difference and popular culture, where the Brazilian intelligentsia were seen as useful in mediating the two:

$[\mathrm{M}]$ echanisms of reinterpretation by the State, through its intellectuals, appropriated popular practices in order to present them as expressions of national culture. Candomblé, carnival, folk pageants, etc., were [all], in this manner, appropriated by the discourse of the State, which in turn considered them as manifestations of being Brazilian

(Ortiz, 1985, p.140)

Third, by merging elements conceived as either foreign or national, where the military, no different from the intelligentsia, took 'ideas out of place' and put them 'in their due place' (Ortiz, 1985, p.31). Therefore, the military's pro-capitalist, protechnology agenda bode well for many Brazilians, as

the structure of classes in Brazilian society ... was becoming analogous to the structure of classes of capitalist societies in general. The ideological contradictions that marked national cultural life in the twentieth-century increasingly approached the ideological contradictions of universal culture, to the extent that they were processing a consolidation of the internationalization of capitalism

(Ortiz, 1985, p.107)

Finally, anthropology and history, with incompatible aims until the work of Freyre, merged within the ideological framework of the military. In other words, by fusing myth with sudden historical change, a balance between anthropology and history was 
struck and a new hybridity emerged that joined legend with actuality, mediated by ideology.

In this last respect, hybridity, or 'unity in diversity', presents an ideologically contradictory question. Is it conceivable that the greater the diversity of a terrain and its people, the stronger the bond between that diversity and the State? Given that the explosive growth of Brazilian television from the 1960s to the 80 s had much to do with the military apparatus, and that the Brazilian television network, Globo, was by far the largest beneficiary of the regime, analysing the Brazilian television mini-series - with its stories closely tied to hybrid national cultures, values and identities - may begin to answer this contradictory question.

\section{Methodological Approach}

Before discussing analysis of the mini-series, I will review the methodological framework of my research. The methodology entails three avenues of textual analysis: first, analysis of the texts and genre of the mini-series, second, analysis of writing on mini-series in the Brazilian press, and third, analysis of interviews with mini-series creators. With each method, key questions are posed. For analysis of television texts: What aspects of Brazilian culture, values and identity are represented in the miniseries texts? How do textual qualities define genre? How is the genre defined by the texts? For press material: How does the press respond to mini-series? What does this say to, and about, the viewing public? What discourses emerge from these responses? What do these discourses say about the representation of Brazil (cultural identify), and responses to that representation (cultural identification)? And for interview transcripts: How are Brazilian culture, values or identity conceived by mini-series creators? How are they realised? How do creators' perspectives relate to what appears in the texts and to what is conveyed to the public by the press?

With text and genre analysis, my underlying approach is structural and based on Roland Barthes' (2000 [1970], p.113) threefold semiotic model for analysing popular texts. The idea here is that the mini-series text employs myth, 'since myth is a type of speech ... conveyed by a discourse' (Barthes, 2000 [1970], p.109), and thus represents mythical constructs of the Brazilian nation. Approaching the mini-series as a form of mythical speech, each aspect of the representation of Brazil (and that represented of Brazil) in the primary research question is aligned with the three components of Barthes' semiotic model: national cultures act as the signifier, national values act as the signified, and national identities act as the sign, where each component of this semiotic model is related to its contingent components, leading to an ultimate reading of the sign as representative of national identity.

While this approach provides a good foundation for textual analysis, the results can be broad and vague. Multiple signifiers of culture lead to ambiguous relations with signified values and, thus, arbitrary or potentially misread signs of national identity. I amended Barthes' semiotic model with more specific analysis of television texts in the literature (Allen, 1987; Anderson, 1985; Barker, 1985; Chesebro, 1978; Feuer, 1985; Geraghty, 1981; Gomery, 1983; Schudson, 1980; Timberg, 1981), which address a more specific and operational range of formulaic, industrial and socioculturally reflective aspects of television programmes as popular texts. As these 
additional analytical approaches correspond with micro-to-macro features of the television texts concerned, I have configured them in an analytical model that works outward from episodic factors (discrete texts) to formulaic factors (the genre), to industrial factors (producers, networks), to shifts in the texts and genre over time (years, decades, eras), and, finally, to reflection of the 'real-world' (representation of social and cultural issues, both current and retrospective).

I consider genre analysis an extension of textual analysis: how the composite qualities of discrete mini-series texts reflect characteristics of the genre. In other words, I examine how the corpus of texts acts as a kind of text unto itself. Additionally, genre analysis is based on literature (Allen, 1995; Bell, 1988; Creeber, 2001a; Creeber, 2001b; Feuer, 1992; Hagedorn, 1995; Lopez, 1995; Neale, 1980; Neale, 2001; Nelson, 2001; Rêgo, 2003; Seiter, 1992; Torodov, 1975; Torodov, 1990; Turner, 2001; Wright, 1975) of genres of the telenovela, soap opera, series, serial, Western film, and novel.

These studies can be synthesised into three basic approaches to genre: the ritual approach, where genre is determined by exchanges between producers/networks and audiences, the ideological approach, where genre is determined by the producer/network as a means controlling audiences, and the aesthetic approach, where genre is determined by the author/creator as an authorial statement or creative signature. I do not regard the Brazilian mini-series, or any other television genre for that matter, as entirely reflecting one of these approaches; rather, I see the mini-series reflecting a hybrid configuration of all three approaches. In fact, such a holistic approach to genre analysis comes from Steve Neale, for whom genre is defined 'not $\ldots$ as forms of textual codifications, but as systems of orientations, expectations and conventions that circulate between industry, text and subject' (1980, p.19). These systems, therefore, can be correlated with the ritual, ideological and aesthetic approaches above in an analytical model that considers three systems: systems of orientations as the ideological approach and industry-oriented, systems of expectations as the ritual approach and viewer-oriented, and systems of conventions as the aesthetic approach and author-oriented, where integrating these approaches factors the text's influence on the genre, the genre's influence on the text, and industrial, receptive and authorial indicators, all of which inform analysis of the miniseries genre.

I approach discursive analysis of press material as yet another kind of textual analysis (see Gill, 2000, p.172). Here, and similar to texts and genre, I consider the discrete article in addition to the corpus of articles on a mini-series production and in parallel to articles and the corpus of writing on other productions. Additionally, I approach discourse analysis as a method that mediates the subjectivity of my own analysis and the objectivity of journalism and the institution of the press (see Hallin \& Mancini, 2004 , pp. 22 - 26). From this mediating role, and from the literature of similar studies using press material to identify discourses in popular television programming (Costera Meijer, 2001; Costera Meijer, 2005; Dhoest, 2004; Koukoutsaki, 2003; La Pastina, 2002), key discourses (and questions) emerge, including speech and grammar (What does the press say? How do they say it?), theory vs. practice (How does what the press says differ from theoretical claims, textual-generic analysis, and interviews?), information gaps (What does the press reveal that textual analysis and interviews omit, or represent differently?), and the institute of the press (What relations exist 
between the Brazilian press and Brazilian television? What are the objectives and values of the press? What is assumed of its readers, viewers, and reader-viewers?).

With the method of interviewing, I look for relations between representations of the 'national story' of the television mini-series and the professional stories of mini-series creators. In other words, I seek to connect personal-professional with textual-generic narratives through the re-presentation of both these accounts. I also look for relations between the primary research question and how national cultures, values and identities are conceived and regarded by mini-series creators in the narrative elements of their work. My specific approach to interviewing is the semi-structured, individual interview. It includes a range of professionals involved in mini-series creation and is based on consideration of a number of similar or divergent approaches in a body of literature (Berger, 1988; Blumler \& Spicer, 1990; Costera Meijer, 2001; Costera Meijer, 2005; Deacon, et al., 1999; Dhoest, 2004; Gaskell, 2000; Koukoutsaki, 2003; Kvale, 1996). However, drawbacks to this approach are the limited free time of television professionals, the difficulty involved in obtaining the commitment of an interview, and the constant migration of television workers between projects and employers.

On the empirical front, I spent six months in Brazil, primarily the city of Rio de Janeiro, but also in São Paulo, from October 2006 to April 2007, collecting textual, press and interview data. In this period, I watched and took notes on 25 mini-series texts, conducted nine interviews and collected approximately 500 newspaper and magazine articles. From this initial phase of fieldwork, a few empirical issues arose. First, the texts viewed and notated were only those most popular or symbolically significant and therefore commercially available. Second, the quantity of press material collected was so great that it was difficult to discern useful from unhelpful material. Third, the small number of interviews conducted thus far created an imbalance in relation to the quality and quantity of the data from the other methods. Subsequent fieldwork was undertaken and concluded, the data and analysis of which is not included in the following discussions. However, there are some interesting and significant initial findings on the role of the mini-series in Brazilian culture and society, the kinds of representations the mini-series makes and the ways in which its representations may be identified by Brazilian viewers through the texts, genre, press and interviews that constitute the rest of this discussion.

\section{Broadcasting Analysis}

Initial analysis does not start with the mini-series texts themselves, nor press material, nor interviews, but rather with the mini-series in the space of nightly television broadcasting in Brazil. This is in order to properly frame and contextualise subsequent discussions of more detailed textual, generic, discursive and professional aspects of the mini-series, which follow.

In the broadcast space of Brazilian nightly television, as the introduction mentioned, the telenovela predominates: episodes air year-round, from Monday through Saturday, at six-, seven- and nine-o'clock without fail. The mini-series, on the other hand, only airs around special occasions such as between New Year's Day and Carnival, during other holidays, or around nationally symbolic or commemorative events. 
Additionally, mini-series air from Tuesday to Friday, leaving nearly as much of the week free; this is significant in comparison to the one day of the week, Sunday, when the telenovela is not broadcast. Finally, mini-series air inconsistently, starting anywhere from ten-o'clock at night to nearly midnight, after programmes considered more important (and commercially successful), like football matches, political messaging and reality television programming.

In a larger sense, these parameters indicate two opposing discourses on the telenovela and mini-series, their audiences, and the exchange of orientations, expectations and conventions entailed therein. The telenovela reflects regularity, fixity and dependability: qualities associated with the demands of the working world and values assumed of those who must adhere to them. In fact, telenovela scheduling follows that of many working-class Brazilians, for whom Sunday is the only free day of the week. The mini-series, on the other hand, reflects occasion, fluctuation, impermanence and temporariness: qualities linked to leisure time and values inferred of those with more latitude in their everyday lives. Compared with the rigor of the telenovela, its explicit orientations, expectations and conventions as much as those implied of its audiences, the mini-series defines any similarly constraining parameters characterised instead by its specificity of occasion.

Another aspect of this contextual analysis of the telenovela and mini-series involves a broad comparison of formulaic standards of 15 mini-series (sampled from the overall population of texts) with those of telenovelas analysed elsewhere (van Tilburg, 2002). This comparison reveals that the telenovela tends to employ a standard battery of shots, evenly paced cuts between shots and scenes, static imagery and often two characters in dialogue. Mini-series, in contrast, employ a greater variety of shots, changeable shots and scene durations, pans over static imagery or greater camera movement in general, and group dialogue or individuals interacting with their environment (instead of with each other). Finally, mini-series draw on a diverse range of sources - novels, folklore, films and theatre - while the telenovela is usually made for television. Thus the 'iconic codification' (van Tilburg, 2002, p.30) of the telenovela, its fixed and standardised techniques that mirror working-world values, gives way to the thematic codification of the mini-series - a greater formulaic shift towards representing thematic change and exchange instead of simple iconic regularity - when assessing the mini-series by the same formulaic standards as the telenovela.

\section{Text and Genre Analyses}

Moving from the broadcasting space and its formulas to how the mini-series actually represents Brazil, I analysed the representation of values in the same sample of 15 mini-series. Among different findings, I observed three predominant, recurring sets of values: moral, normative and ideological (or personal, social, and political). However, I also found the representation of these values not to be discrete among texts; rather, there is overlap, exchange and conflict between how these values are depicted among and between the sampled texts. For instance, in six mini-series, there is a prominent exchange between characters' personal values and the social values emblematic of their setting. In other words, this is a clear set of representations of how characters' morals may impact the norms of their social environment and, in turn, a subsequent 
set of representations of how these normative values return to impact characters, transforming their lives. In four other mini-series, representations instead focus on an exchange between characters' moral values and the ideological values of era, church or State; that is, how a character's personal values affect historical, religious or political events in Brazil. Finally, five different mini-series reveal an exchange between all three kinds of values. Characters' moral values shape their environment's social norms, which in turn transform political, historical or religious contexts and conditions in Brazil. However, these moral-to-ideological transformations also invariably return to influence the personal ambit of the characters themselves.

Regarding the micro-to-macro features of textual analysis outlined in the methodology, it is useful to illustrate how micro-level features such as casting, set design and lighting affect macro-level features such as the representation of historical eras or 'real-world' social-cultural issues (see Figure 1). First, there is the 'axial character' arrangement (Barker, 1985, pp. 180-188), in which the narrative circulates around central or solitary characters. In mini-series of this casting structure, narratives have a distant and remote quality, often adapted from older works of literature or mythical sources like the Western or children's tales, as if to reinforce the existential condition of these sources' lone protagonist confronting a hostile or unjust world. This structure expands to core-groups of characters in other mini-series, with anywhere from two to about five central protagonists, in which narratives circulate around more contemporary or time-sensitive themes, even if the latter are depicted retrospectively. Finally, there is the full 'ensemble cast' (Barker, 1985, pp. 180-188) with seven or more central characters, where narratives are concerned with historical events epic in nature, such as civil war, national independence or abrupt political change. 

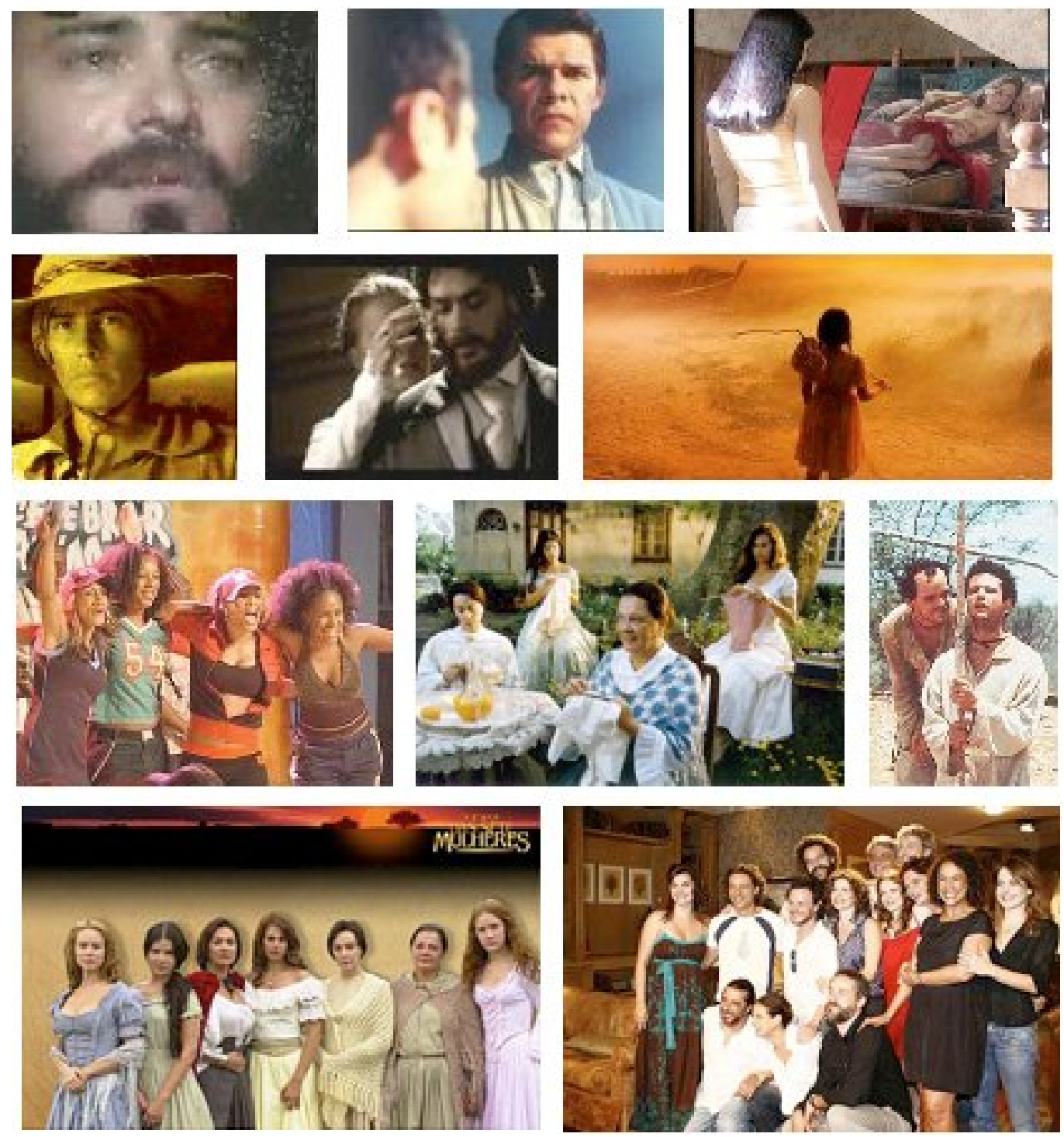

Figure 1: Mini-series' axial, core and ensemble character structures.

Set design and lighting tend to reflect these casting structures (see Figure 2). In texts with axial character arrangements, sets and lighting tend to be darker, moodier, more introspective and insular. In texts with core-groups, set design and lighting opens up, becoming brighter and less introspective, incorporating a greater amount of the exterior and characters interacting with their environment. In texts with an ensemble cast structure, there is an even greater degree of interaction with setting or environment; for example, even larger-scale, expansive exterior scenes, as these narratives tend to portray change in the physical or ideological attributes of Brazil, whether by virtue of land loss/acquisition, power disputes, or civic/political rights. 

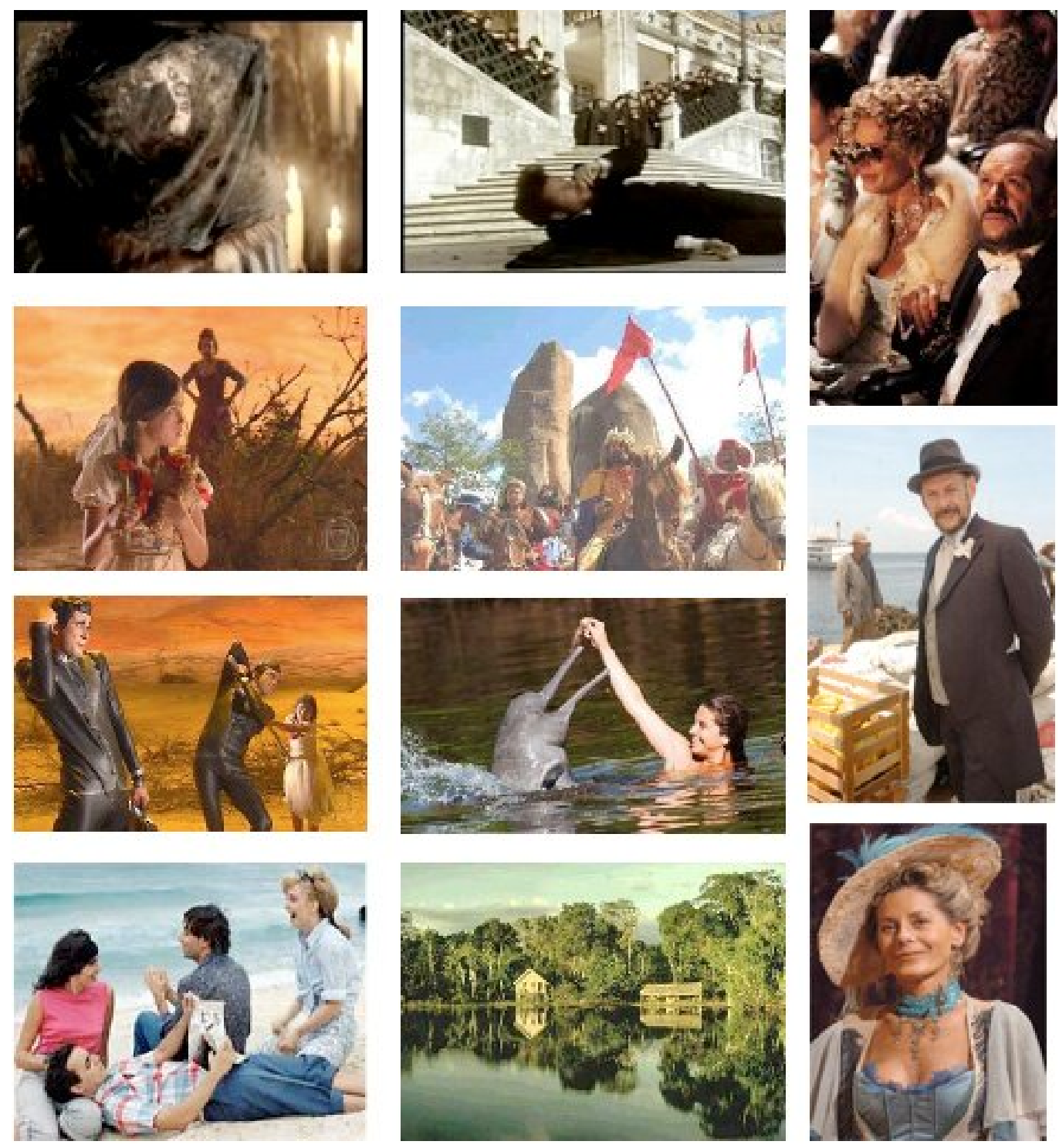

Figure 2: Casting, set design and lighting features.

Particularly significant among the sampled texts is the emergence of the micro-series, representing day-to-day lives in the favelas of Rio de Janeiro and São Paulo. In the micro-series Cidade dos Homens (Globo, 2002-2005), for example, the narrative surrounds two central characters; however, elements of set design and lighting fuse the dark, claustrophobic, interior spaces of axial-character texts with the bright, open exteriors of core- or ensemble-cast texts, with the favela a constant backdrop to plot and character development (see Figure 3). Cidade dos Homens also incorporates the 'in-between' spaces of the characters' everyday existence: the corridors, stairways and passageways of their favela, as well as the public transport, streets and beaches of Rio de Janeiro, which invariably reflect the dramatic social divisions of that city. In achieving these kinds of unprecedented representations, this micro-series relies on a greater use of cinematic and experimental techniques, like first-person perspectives, documentary-style filming, black-and-white footage, hand-held cameras, and stillimagery montage. Through these innovative devices, the text is not only a 
documentation of Brazil's urban peripheries, but also a means of interacting with them, conveying an under-represented set of cultures, values and identities more than merely employing alternative rhetorical techniques.
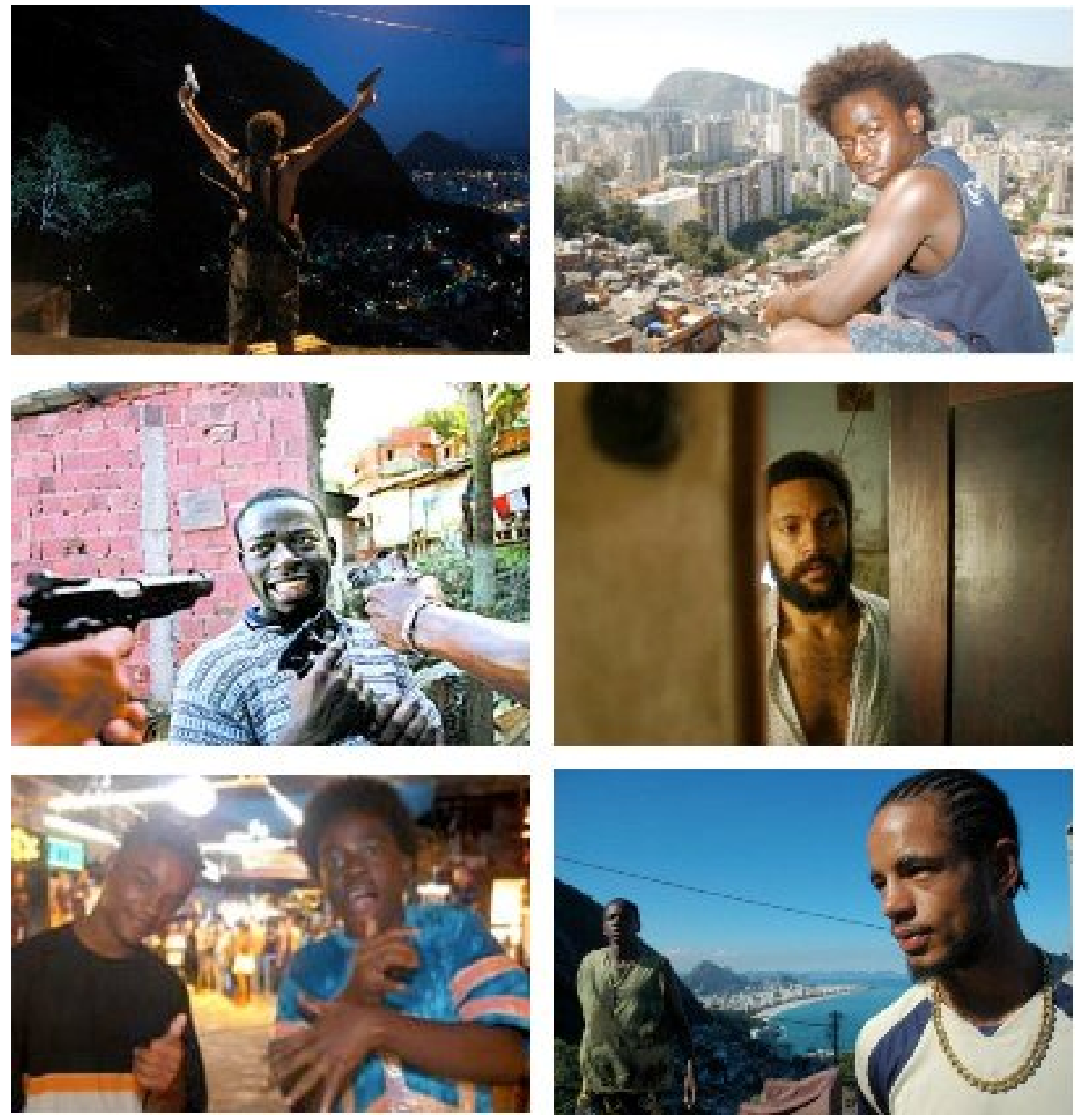

Figure 3: Cidade dos Homens.

Extrapolating a firm sense of the mini-series genre from its hybrid qualities is difficult. Nevertheless, by analysing the sampled texts with the integrated approach to genre analysis above, I have made a few generic findings. In terms of systems of industry orientation, or the ideological approach, and due primarily to implications of the broadcasting and scheduling parameters discussed above, the mini-series becomes an 'exclusive' kind of programme. Due to this exclusivity, the mini-series also serves as a canvas for its creators' artistic latitude, as well as a portfolio for the networks' financial and creative resources.

Regarding systems of expectations, or the ritual approach, mini-series most popular with viewers are perhaps as diverse as the entire corpus of texts: they depict contemporary as much as historical Brazil, they draw on 'high' as much as 'popular' 
culture, and they are set in the coastal cities of Brazil as much as the rural hinterlands. Thus any expected, ritual success of a mini-series indeed relies on this exchange between viewers and producers, most likely based on the success of past productions, but certainly takes this more dialogic approach into account.

With a system of conventions, or the aesthetic approach, there are few dedicated miniseries creators, although, within this small corps of professionals, styles vary greatly. Some creators only adapt works of literature, others only popular tales; some draw heavily on their extra-textual, cinematic/theatrical repertoires, others on the conventions of the telenovela; others still invoke farther-flung traditions like the Western film or the pornochanchada (the 'pornographic spoof'). Unlike systems of orientations or expectations of the ideological and ritual approaches, however, an entirely convention- or aesthetically-driven mini-series can (and often does) evolve in an artistic vacuum, thus devoid of the industrial or ritual influences that otherwise ensure its success.

\section{The Press and Interview Analyses}

To provide an adequate perspective on creation of, and response to, the Brazilian mini-series, as well as how its representations are respectively produced and received by its creators and the press, I focus here on two mini-series in particular. First, the mini-series Os Maias (Globo, 2001) is the story of an elite, Portuguese family's dark secrets and how these eventually lead to the family's demise. The text is a detailed, rich, cinematic experience, relying on the fidelity of the mini-series to the nineteenthcentury novel. This is further supported by elaborate costumes and exotic settings: again, the authenticity of aesthetics and values of the era and location. Slow-paced, sombre, noir-like textual elements like dark clothing, concentrated lighting, interior settings, and motifs of mirrors and candles all represent a distant and obscure culture. Furthermore, characters develop through peaks and valleys of anguish and elation, betrayal and revenge.

The micro-series Antônia (Globo, 2006-2007) is about four young working-class black women from a São Paulo favela attempting to succeed with their hip-hop music. Like Cidade dos Homens, the text integrates the tight spaces, narrow corridors, steep passageways, and generally clandestine conditions of their favela with plot and character development. But these restrictive conditions are combined with the open space of rooftops or sweeping views of São Paulo in the distance, where the characters go to be alone and reflect, or to come together and share their common struggle. Antônia represents the reality of day-to-day life in a São Paulo favela, which also involves depicting cultures of drug trafficking, crime, violence and poverty endemic to these communities, as well as the impact this has on characters' values and identities. However, between these physical and psychical hardships, the text represents identities and values common to the characters and their viewers: family, friendship, hard work and success.

In analysing interviews and press analysis, I discerned clear discursive patterns that reflect these mini-series' textual differences, but, more so, that correlate with how these texts' representations are differentially conceived and received. I interviewed a producer of Os Maias, who highlighted the importance of representing 'erudite 
culture', yet 'without appearing to do so' for viewers. He continued, 'culture' should be 'neither erudite nor fluffy'; that is, popular elements need to be 'mixed' with erudite elements in order for the mini-series to appeal to all viewers. In the end, however, there's one audience 'you just have to have', implying a less-than-ideal audience. And who comprises this audience? 'They're poor people'. Thus, an 'erudite text' like Os Maias needs to be even 'more appealing' to retain marginalised viewers, who, because of the demands of the working world, go to bed early and otherwise miss late-night broadcasting.

The press directly invokes mini-series creators' words, which convey a sense of disappointment in viewers' lacklustre response to Os Maias. While viewers have been offered 'the best of Brazilian television', 'well-spoken Portuguese' and 'rich historical narratives', they have not responded as they should have. But this is all understandable, as viewers have been 'dumbed-down by the massification' of typical Brazilian television fare.

With Antonia, the words of producers and the discourses of the national press differ significantly, commensurate with the difference in textual representations. One producer I interviewed emphasised the 'centrality of music to urban culture' and, in particular, the importance of independent music production to peripheral communities of Brazil. Her focus was also on 'alternate means of communication' and distribution: 'the word-of-mouth' exchange and interpersonal contact that take place in Brazil's urban peripheries as a sole recourse to exclusion from 'mainstream channels' of media production and distribution. Also, this producer stressed representing 'the good side of the bad' in the micro-series: how the favela is intended to represent a 'normal place', with people who 'lead normal lives' and hold values akin to their 'mainstream' television-viewer counterparts. Nevertheless, she concluded, Antonia also represents a divided Brazil, or 'countries within a country'.

Discourses from the press compliment this producer's testimony, but are even more optimistic. There is a stress on the importance of independent music to the microseries, but with the protagonists and their ambitions in sharp contrast to the "maledominated rap industry'. Thus, discourses establishing cultural identity through 'a deep and profound friendship' emerge, particularly when 'subordinated' by conditions of 'gender, race, and social class'. Finally, a broader discursive invocation of the 'history of Afro-Brazilian music' (such as samba and brega) appears, and how Antônia 'seeks to rescue these traditions'.

\section{Conclusions}

There are sets of conclusions to make on the empirical and theoretical levels. Empirically, and in spite of theoretical claims, there do not seem to exist neat correlations between the working-world, working-class cultures, values and identities of the telenovela and its viewers, and the middle-class cultures, values and identities of the mini-series and its viewers. This is based on empirical observations of the hybridity of representations and textual devices employed in the mini-series, particularly in comparison with representative and textual homogeneity of the telenovela. 
However, given micro-to-macro aspects of the texts of both genres, there are perceptible patterns to be concluded from each. With the telenovela, there are fixed scheduling, continuous episodes, expected engagement, and formulaic techniques: in sum, an emphasis on action and dialogue, perhaps accentuated by the conditions of the working world. With the mini-series, there are well-anticipated broadcasts hampered by unpredictable scheduling, short-run productions, and diverse techniques: or, emphases on contemplation, varying social-cultural conditions and increased interaction with one's environment. In other words, the mini-series reflects a series of special conditions and occasions, as well as how leisure time allows for contemplation over action. Thus the mini-series relies to a greater extent on explicit representations of complex and changing cultures, values and identities among, and for, Brazilians, reflected in the texts, anticipated by producers and noted by the press.

On the theoretical level, Hall's systematic play of differences between the cultures, values and identities represented in the individual and corpus of mini-series texts is apparent. Also apparent are the ways these representations come into contact with each other, clash and are negotiated between characters, plots, texts and the genre on the whole. There is also a discernable tension, to confirm Bhabha's claims, between the pedagogical and performative dimensions of the postcolonial condition: the miniseries, in other words, as both a historical document and an agent of representative change. Gilroy's conceptualisation of a double-conscious postcolonial identity resonates as well, particularly in the emerging representations of characters struggling to succeed in the exponential growth of Brazil, yet impeded by indelible legacies. At the same time, García Canclini's notion of the contingent and contextual capacities of social-cultural capital in postmodern Latin America renders the possibility of movement beyond confining modern constraints more likely, if not in fact expected of more recent narratives. Finally, Anzaldúa and Martín-Barbero's conceptualisation of mestizaje resurfaces, in both the making and re-making of Brazil's many stories, on the social-cultural level explicit of, and the textual-generic level implicit in, the complexity of the term.

However, in not forgetting Ortiz's reading of the co-optive dimensions of hybridity leveraging Brazil's diverse terrains and peoples for intellectual and political gain could it be that these complex representational dimensions of hybridity in the Brazilian mini-series are simply a ploy by Globo's vast resources to encompass what it merely appears to entertain? Although this could be true, it is too simple an interpretation. Rather, what emerges is an appeal to 'enlighten' or 'educate' the viewing public through entertainment, not only by the texts themselves, but also by producers' perspectives and journalists' commentaries. Thus what may be an implicit appeal to viewers' working-world values in the telenovela becomes instead an explicit appeal to illustrate and understand the diverse cultures, identities and values of Brazil through the manifold representations of the television mini-series. 


\section{References}

Allen, R.C. (1987) The Guiding Light: Soap Opera as Economic Product and Cultural Document. In: Newcomb, H. ed. Television: The Critical View. $4^{\text {th }}$ ed. Oxford: Oxford University Press

Allen, R.C. (1995) Introduction. In: Allen, R.C. ed. To Be Continued: Soap Operas Around the World. London: Routledge

Anderson, C. (1985) Reflections on Magnum P.I. In: Newcomb, H. ed. Television: The Critical View. $4^{\text {th }}$ ed. Oxford: Oxford University Press

Anzaldúa, G. (2007 [1987]) Borderlands/La Frontera: The New Mestiza. San Francisco: Aunt Lute Books

Barker, D. (1985) Television Production Techniques as Communication. In: Newcomb, H. ed. Television: The Critical View. $4^{\text {th }}$ ed. Oxford: Oxford University Press

Barthes, R. (2000 [1970]) Mythologies. London: Vintage

Bell, M.W. (1988) F.R. Leavis. London: Routledge

Berger, A.A. (1988) Media Research Techniques. $2^{\text {nd }}$ ed. London: Sage

Bhabha, H.K. (1994) The Location of Culture. London: Routledge

Bhabha, H.K. (1996) Culture's In-Between. In: Hall, S. and du Gay, P. eds. Questions of Cultural Identity. London: Sage

Blumler, J.G. and Spicer, C.M. (1990) Prospects for creativity in the new television marketplace: evidence from program-makers. Journal of Communication. 40(4): 78101

Bourdieu, P. (1977) Outline of a Theory of Practice. Cambridge: Cambridge University Press

Bourdieu, P. \& Passeron, J-C. (1990) Reproduction in Education, Society and Culture. $2^{\text {nd }}$ ed. London: Sage

Chesebro, J.W. (1978) Communication, Values, and Popular Television Series - A Four-Year Assessment. In: Newcomb, H. ed. Television: The Critical View. $4^{\text {th }}$ ed. Oxford: Oxford University Press

Costera Meijer, I. (2001) The colour of soap opera: an analysis of professional speech on the representation of ethnicity. European Journal of Cultural Studies. 4(2): 207230.

Costera Meijer, I. (2005). "Impact or Content? Ratings vs Quality in Public Broadcasting”. European Journal of Communications. 20(1): 27-53 
Creeber, G. (2001a) The Mini-Series. In: Creeber, G. ed. The Television Genre Book. London: British Film Institute.

Creeber, G. (2001b) Taking our personal lives seriously: intimacy, continuity and memory in the television drama serial. Media, Culture \& Society. 23(4): 439- 455

Deacon, D. Pickering, M. \& Golding, P. (1999) Dealing with Documentation. In: Researching Communications: A Practical Guide to Methods in Media and Cultural Analysis. London: Hodder Arnold

Dhoest, A. (2004) Negotiating Images of the Nation: The Production of Flemish TV Drama, 1953 - 89. Media, Culture \& Society. 26(3): 393-408

Du Bois, W.E.B. (1996) The Souls of Black Folks. New York: Penguin

Feuer, J. (1985) The MTM Style. In: Newcomb, H. ed. Television: The Critical View. $4^{\text {th }}$ ed. Oxford: Oxford University Press

Feuer, J. (1992) Genre Study and Television. In: Allen R.C. ed. Channels of Discourse, Reassembled: Television and Contemporary Criticism. London: Routledge

Freyre, G. (1946) The Masters and the Slaves [Casa-Grande e Senzala]: A Study in the Development of Brazilian Civilization. New York: Knopf

Freyre, G. (1986) The Mansions and the Shanties: [Sobrados e Mucambos]: The Making of Modern Brazil. Berkeley, CA: University of California Press

García Canclini, N. (1995a) Hybrid Cultures: Strategies for Entering and Leaving Modernity. Minneapolis: University of Minnesota Press

García Canclini, N. (1995b) Consumidores e Cidadãos: Conflitos Multiculturais da Globalização. Rio de Janeiro: Editora UFRJ

Gaskell, G. (2000) Individual and Group Interviewing. In: Bauer, M.W. and Gaskell, G. eds. Qualitative Researching with Text Image and Sound: A Practical Handbook. London: Sage

Geraghty, C. (1981) The Continuous Serial - A Definition. In: Dyer, R. ed. Coronation Street. London: British Film Institute

Gill R. (2000) Discourse Analysis. In: Bauer, M.W. and Gaskell, G. eds. Qualitative Researching with Text Image and Sound: A Practical Handbook. London: Sage

Gilroy, P. (1993) The Black Atlantic: Modernity and Double Consciousness. London: Verso

Gilroy, P. (2000) The Sugar You Stir ... In: Gilroy, P. Grossberg L. \& McRobbie, A. eds. Without Guarantees: In Honour of Stuart Hall. London: Verso 
Gomery, D. (1983) Brian's Song: Television, Hollywood, and the Evolution of the Movie Made for Television. In: Newcomb, H. ed. Television: The Critical View. $4^{\text {th }}$ ed. Oxford: Oxford University Press

Hagedorn, R. (1995) Doubtless to be Continued. In: Allen, R.C. ed. To Be Continued: Soap Operas Around the World. London: Routledge

Hall, S. (1990) Cultural Identity and Diaspora. In: Rutherford, J. ed. Identity: Community, Culture, Difference. London: Lawrence \& Wishart

Hall, S. (1996) Who Needs Identity? In: Hall, S. \& du Gay, P. eds. Questions of Cultural Identity. London: Sage

Hall, S. (2001) The Multicultural Question. Milton Keynes: Pavis Centre for Social and Cultural Research, Faculty of Social Sciences

Hallin, D.C. and Mancini, P. (2004) Comparing Media Systems. In: Hallin, D.C. \& Mancini, P. eds. Comparing Media Systems: Three Models of Media and Politics. Cambridge: Cambridge University Press

Koukoutsaki, A. (2003) Greek television drama: production policies and genre diversification. Media, Culture \& Society. 25(6): 715-735

Kvale, S. (1996) InterViews: An Introduction to Qualitative Research Interviewing. London: Sage

La Pastina, A.C. (2002) The sexual other in Brazilian television: public and institutional reception of sexual difference. International Journal of Cultural Studies. 5(1): 83-99

Lopez, A.M. (1995) Our Welcomed Guests: Telenovelas in Latin America. In: Allen, R.C. ed. To Be Continued: Soap Operas Around the World. London: Routledge

Martín-Barbero, J. (1993) Communication, Culture and Hegemony: From the Media to Mediations. London: Sage

Martín-Barbero, J. \& Rey, G. (2001) Os Exercícios do Ver: Hegemonia Audiovisual e Ficção Televisiva. São Paulo: Editora SENAC

Neale, S. (1980) Genre. London: British Film Institute

Neale, S. (2001) Studying Genre. In: Creeber, G. ed. The Television Genre Book. London: British Film Institute

Nelson, R. (2001) Studying Television Drama. In: Creeber, G. ed. The Television Genre Book. London: British Film Institute

Ortiz, R. (1985) Cultura Brasileira e Identidade Nacional. São Paulo: Editora Brasiliense 
Ortiz, R. (1988) A Moderna Tradição Brasileira: Cultura Brasileira e Indústria Cultural. São Paulo: Editora Brasiliense

Ortiz, R., Ortiz Ramos, J.M. \& Simões Borelli, S.H. (1989) Telenovela: História e Produção. São Paulo: Editora Brasiliense

Rêgo, C. (2003) Novelas, Novelinhas, Novelões: The Evolution of the (Tele)Novela in Brazil. Global Media Journal, [Online]. 2 (2),

Available from: http://lass.calumet.purdue.edu/cca/gmj/sp03/gmj-sp03-rego.htm [Accessed 14 November 2004]

Schudson, M. (1980) The Politics of Lou Grant. In Newcomb, H. ed. Television: The Critical View. $4^{\text {th }}$ ed. Oxford: Oxford University Press

Seiter, E. (1992) Semiotics, Structuralism, and Television. In: Allen, R.C. ed. Channels of Discourse, Reassembled: Television and Contemporary Criticism. London: Routledge

Timberg, B. (1981) The Rhetoric of the Camera in Television Soap Opera. In: Newcomb, H. ed. Television: The Critical View. $4^{\text {th }}$ ed. Oxford: Oxford University Press

Torodov, T. (1975) The Fantastic: A Structural Approach to a Literary Genre. Ithaca, New York: Cornell University Press

Torodov, T. (1990) Genres in Discourse. Cambridge: Cambridge University Press

Turner, G. (2001) The Uses and Limitations of Genre. In: Creeber, G. ed. The Television Genre Book. London: British Film Institute

van Tilburg, J.L. (2002) A Televisão e o Mundo do Trabalho - o poder de barganha do cidadão-telespectador. [Online].

Available from: Biblioteca de Ciências da Comunicação, Universidade da Beira Interior http://www.bocc.ubi.pt [Accessed 2 February 2006]

Wright, W. (1975) Sixguns and Society: A Structural Study of the Western. Berkeley, CA: University of California Press 